\title{
Anecdotes to the life and times of Sir Richard Owen (1804-1892) in Lancaster
}

\section{Q Wessels and AM Taylor}

\begin{abstract}
Sir Richard Owen, a Lancastrian, was a prominent biologist, comparative anatomist, geologist, palaeontologist and known for coining the term dinosaur. His expertise in anatomical dissection proved to be one of his biggest assets and aided his career progression at the Royal College of Surgeons and the Zoological Society. Owen’s apprenticeship in Lancaster helped him to gain expertise in anatomy and anatomical dissection. The authors aim to provide some novel contextual background to his childhood in Lancaster, his affection for his hometown and his contribution to Lancaster's sanitary reform. The latter aspect of his scientific accomplishments is typically overlooked.
\end{abstract}

Key words: Sir Richard Owen, Lancaster, apprenticeship, sanitary reform

\section{Introduction}

The Royal Society of Biology spearheaded a unique project in the months of February and March of 2015 to commemorate the renowned and sometimes uncelebrated champions of biology. The scheme saw the unveiling of ten blue plaques across the United Kingdom and included a ceremony in honour of Sir Richard Owen on the 26th February, at the Lancaster Royal Grammar School (LRGS), East Road, Lancaster. ${ }^{1}$ Sir Richard Owen was born on 20 July 1804 at Thurnham Street, Lancaster, Lancashire. He was one of six children of Richard Owen (1754-1809), a merchant, and Catherine "Kitty" Parrin (1760-1838), a descendent of 
the Huguenots from Provence. Catherine was a musician and the young Owen never ceased to mention his mother's charm and manners ${ }^{2,3}$ Owen's grandson and biographer, Rev.

Richard Startin Owen, noted that the young Richard's father was the complete opposite and proved to be stubborn and pretentious. Much has been written on the life, scientific discoveries and accomplishments of Sir Richard Owen and these writings also include the controversies surrounding his persona, his stout opposition of Darwin's theory and his unjust credit for the discovery of nematode Trichina spiralis. ${ }^{2,4-9}$ Owen was an anatomist of international acclaim and was later credited for the discovery of the parathyroid glands, or the glands of Owen, and he also became the eponymist for the ultrastructural lines across dentine caused by irregularities in the axis of dentin tubules, known as Owen's Lines. ${ }^{5,10}$ Numerous authoritative publications resulted from his eclectic research., ${ }^{2,5}$ No attempt can be made here to give an adequate account of his career. Sir Richard Owen was considered by some to be a jealous show-off who stole the honours from his juniors. As Bett in $1954{ }^{5}$ pertinently asked; 'how out of such confusion of contradictions shall we sketch Richard Owen today?'

The aim here is to provide a sketch of Owen's life and contribute to the narrative of Owen's life with particular reference to his place of birth at Lancaster. Owen's reach extended beyond the natural sciences to that of public health. Owen's biographer notes that his most eventful years were between 1844 and 1846 and this period also coincided with his involvement with the Sanitary Reform. ${ }^{2}$ He made a significant contribution to Sanitary Reform in Victorian England, particularly in Lancaster. These efforts are typically overlooked due to his achievements in anatomy, geology and palaeontology and will be highlighted in this essay. 


\section{Lancaster and Owen's Apprenticeship}

Richard Owen entered what is now known as the Lancaster Royal Grammar School (LRGS) in 1810 and continued his education until 1819. ${ }^{2,11}$ Richard Owen senior died at the Island of Bartholomew, in the West Indies, on the 14 October 1809 and the young Richard continued to live with his mother and siblings at Thurnham Street. ${ }^{2,3}$ Owen's time at LRGS coincided with that of Rev. Joseph Rowley (1772-1864), who served as headmaster from 1802-1812. ${ }^{11}$ Rowley, with time, developed a high regard as a result of the eminent students reared under his leadership. Rowley also served as chaplain to the county gaol at Lancaster Castle (Fig. 1A) and witnessed 168 executions during his 50 years of service. ${ }^{3,11,12}$ Owen knew Rowley outside of the academic setting, he became Rowley's godson and he always referred kindly to Rowley, or Parson Rowley as he was more affectionately known. ${ }^{11}$ This close relationship was further strengthened by the fact that Owen's mother and Rowley lived next door to each other in Lancaster. ${ }^{11,12}$ The most distinguished of Rowley's pupils were Owen and William Whewell (1794-1866) (Fig. 1B). Owen and Whewell became the best of friends in the years that followed, in spite of Owen's initial taunting of Whewell. Whewell raised the standard of mathematics and academic performance, and underachievement was subsequently rewarded with penalties. Owen, who had no liking for study, expressed his feelings of disgust in the shelter of his older brother James. Whewell rebuked the two boys by handing them a few black eyes. ${ }^{2}$ This lack of enthusiasm for study was shown by Owen's repeated episodes of mischief and his inability to hide his guilt. Roper ${ }^{12}$ alludes to this from an unknown source detailing the fact that Owen's eyes would give himself away:

'Then sparkling most in mirth and joyousness;

In mischief too seldom, shall I say, 
The most famous quote regarding Owen relates to his boyhood persona and refers to him as being 'lazy and impudent'. Owen's tutor, an instructor of calligraphy, stigmatised him as lazy and insolent according Owen's biographer. ${ }^{1,2}$ It is suspected that these thoughts were most likely those of John Crone (of whom little is known), Writing Master at LRGS, who referred to Owen as follows: ${ }^{11}$

'Owen, thoo's lazy and thoo's ignorant, and thoo'll never mend'

(a)

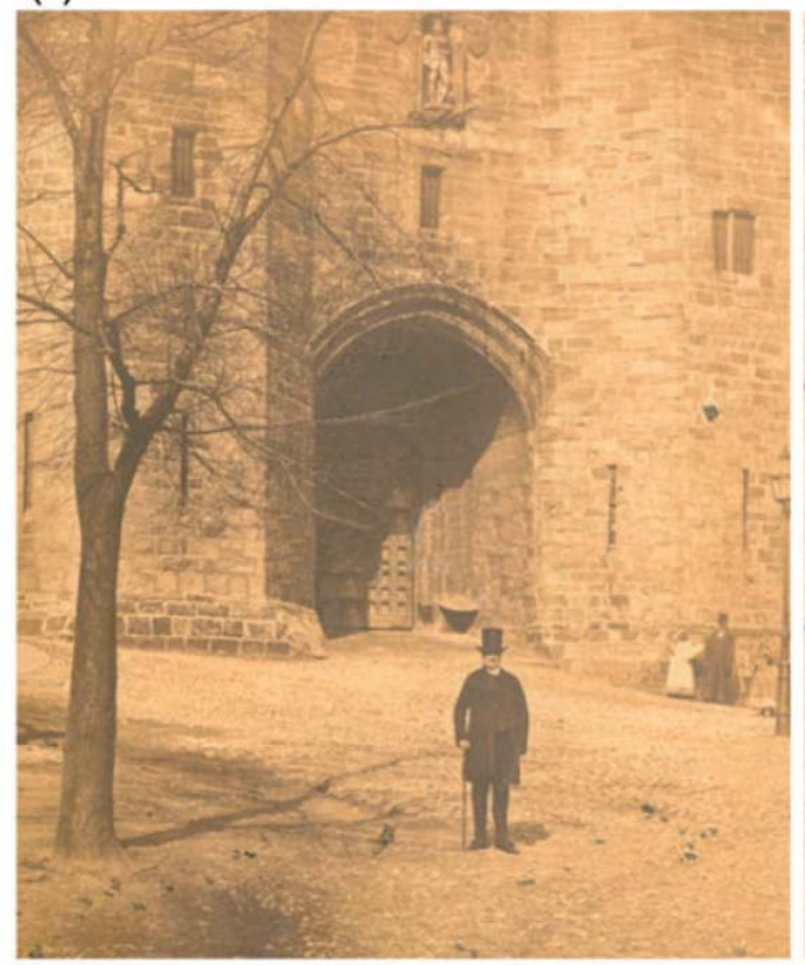

(b)

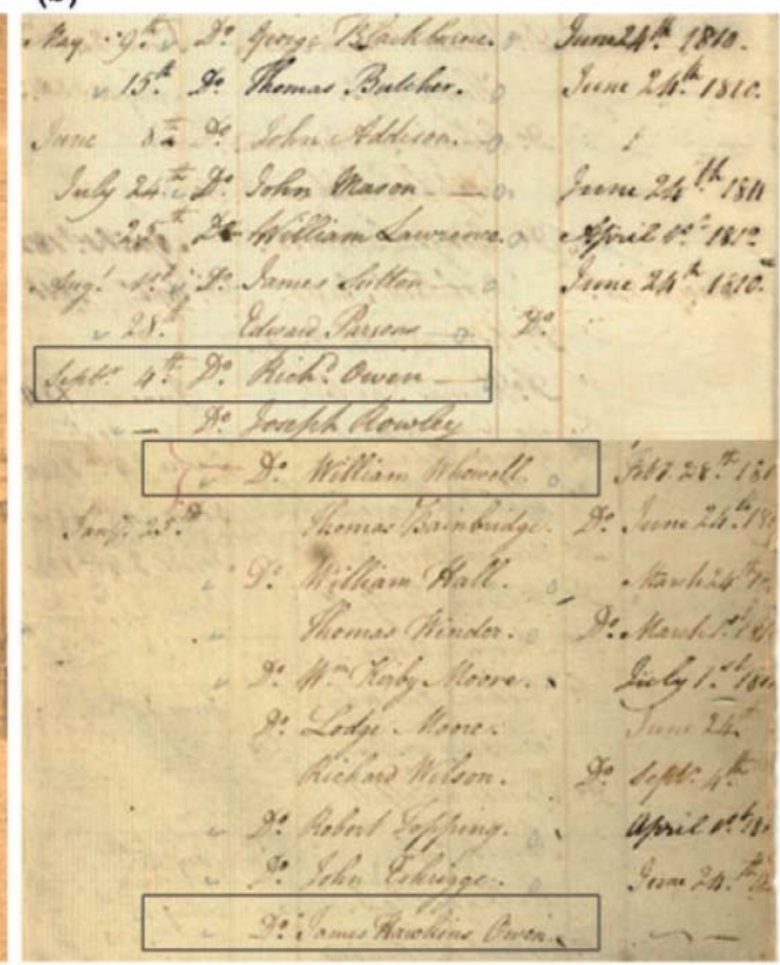

Fig. 1 A: Rev. Joseph Rowley, Owen's godfather, taken at Castle Hill (1858) with John O' Gaunt's gatehouse in the background. The castle played a significant role in kindling Owen's love for anatomy and developing his skill in anatomical investigation. B: Images from the school catalogue (1810) documenting the entry of Richard Owen (top) and William Whewell (middle) into the school register (bottom). The name of Owen’s older brother, James, also appears in the register. 
Despite these gloomy predictions and the stark contrast of his father's views, Richard Owen was taught to write outstandingly clearly and neatly with little variation throughout his life. ${ }^{2}$ Owen also proved to be well versed in Latin and he once impressed a Quernmore farmer by reciting the rule that determines the gender of nouns in an attempt to collect a customary donation. Owen's influence and memories at LRGS have remained over the years. Former LRGS pupils are known as 'Old Lancastrians' and numerous branches of the club exist in the U.K. and worldwide. ${ }^{11}$ Owen became the first president of the Old Lancastrians' Club and its noteworthy members of that era included Sir Edward Frankland (1825-1899), chemist; and Sir William Whewell, polymath and scientist. Excellent academic achievement in biology, to date, is rewarded with the coveted Owen Prize for Biology. Owen was further honoured in a bid to revive the LRGS debate society with the establishment of the Owen Society on 9th February 1898. The Owen Society initially served as a platform to discuss various papers and later became a platform for traditional debates and then ceased to exist altogether. In a strange twist of fate, the current Debating Society at LRGS is referred to as the Whewell Society. ${ }^{11}$

Owen's medical training started ominously under the supervision of three local surgeon-apothecaries in August 1820. The first, Leonard Dickson (1768-1822), died at the age of 54, the second, Joseph Seed (1788-1868) , joined the Royal Navy and the last, James Stockdale Harrison (1798-1879), was known to be a drunk. ${ }^{2,3,9}$ Evidence suggests that Owen's time at the gaol under Harrison sparked his love for Anatomy. Harrison delegated to his students, as was later the case with William Senhouse Kirkes (1822-1864), the duty of tending the sick prisoners in Lancaster Castle and he encouraged them to conduct postmortem examinations on the dead., ${ }^{3,13}$ The only legal source of corpses for dissection was from the gallows as stipulated by the Murder Act 1752. The Lancaster Gazette of that period classically states that executed criminals, after hanging for one hour, were 'to be given to the 
surgeons' or 'to be dissected' in the old tower. ${ }^{14,15}$ Little is known about the other responsibilities Owen had as an apprentice and one can only deduce that it entailed the arrangement of patient appointments, general bookkeeping and preparation of prescriptions and medication as was the case with Sir William Turner (1832-1916) during his apprenticeship in Lancaster. ${ }^{16}$ Owen's four years as an apprentice at the gaol coincided with a total of 19 executions by hanging in front of the Assize Court at the rear of the Castle. The executions culminated a wide range of criminal offences including highway robbery and theft (Table 1); eight in 1820 and four in both 1821 and 1822, and finally three in 1824. Records show that there were no executions in 1823 and none of the inmates died of natural causes or so called ill-health. ${ }^{17}$ Owen and the local apothecary-surgeons thus had a good supply of cadaveric material compared to the national shortage of both the private medical schools and universities. ${ }^{19}$ This probably explains how Owen became a skilled prosector and his skill with a knife would later play a significant role in his career at the Royal College of Surgeons and the Zoological Society. The executed criminals were not the only source of anatomical material. Owen's well documented anecdotes of overcoming his supernatural superstitions of ghosts at the gaol and his theft of the head of an Ethiopian slave that was treated as a patient suggests that individuals who succumbed to typhus or gaol fever were also dissected. ${ }^{2}$ Records show that a total of four inmates died of natural causes or ill-health during his time at the gaol. ${ }^{17}$ Three separate infirmaries served the inmates at the gaol and these were for the debtors, males and females and the 1824 report by the prison surgeon, John Smith, for the period between 1 October and 31 December of that year mentions that there were no cases of gaol fever or any other infectious disease. The prisoners were considered to be healthy and only five were treated at the prison hospital. ${ }^{17}$ 
Table 1. List of executions during Owen's time as an apprentice from 1820 to 1824 at Lancaster Castle and it can be safely assumed that a total of 19 corpses were available for dissections. The list also includes some interesting crimes that were punishable by execution if prosecuted. The last public execution by hanging was held on Saturday 25 March 1865 and the last execution by hanging was at 08:00 on 13 August $1964 .^{17}$

\begin{tabular}{|l|c|c|c|c|c|}
\hline Crime & 1820 & 1821 & 1822 & 1823 & 1824 \\
\hline Burglary & 1 & 1 & 3 & 0 & 2 \\
\hline Forgery & 1 & 0 & 1 & 0 & 0 \\
\hline Highway robbery & 2 & 0 & 0 & 0 & 0 \\
\hline Livestock theft (stealing a cow, sheep or horse) & 0 & 0 & 0 & 0 & 0 \\
\hline Murder & 1 & 0 & 0 & 0 & 1 \\
\hline Rape & 0 & 0 & 0 & 0 & 0 \\
\hline Setting fire to a building & 0 & 0 & 0 & 0 & 0 \\
\hline Shooting with the intent to murder & 0 & 1 & 0 & 0 & 0 \\
\hline Sodomy & 0 & 0 & 0 & 0 & 0 \\
\hline Uttering forged notes & $\mathbf{8}$ & $\mathbf{4}$ & $\mathbf{4}$ & $\mathbf{0}$ & $\mathbf{3}$ \\
\hline Total executions & & & & & \\
\hline
\end{tabular}

Lancaster Castle would later, on 14 March 1828, be at the centre of one of the most significant and dramatic changes to the legislation pertaining to the study of Anatomy. ${ }^{18}$ The case of interest involved the exhumed body of Jane Fairclough and the resurrectionists and defendants John Davies (a medical student at the Warrington Dispensary) and Edward Hall (a surgeon and apothecary in practice at Warrington). The incident occurred at High Cliff, 
Appleton, Cheshire, in October, 1827. The case was tried at Lancaster Assizes on 14 March 1828 and the ruling of the presiding judge, Baron Hullock, was as follows: ${ }^{18}$

'... as conspiracy was an offence of serious magnitude, they should be satisfied, before finding a verdict of guilty on the former part of the indictment, that the conduct of the defendants was the result of previous concert. If any of the defendants were in possession of the body under circumstances which must have apprized them that it was improperly disinterred, the jury would find them guilty of the latter part of the charge. The only bodies legally liable to dissection in this country were those of persons executed for murder. However necessary it might be, for the purposes of humanity and science that these things should be done, yet, as long as the law remained as it was at present, the disinterment of bodies for dissection was an offence liable to punishment.'

This trial along with public outcry as a result of the activities of John Bishop, together with Thomas Williams, Michael Shields and James May, known as the London Burkers, modelled on the modus operandi of Edinburgh's Burke and Hare, played a pivotal role in passing a new Bill and the development of the 1832 Anatomy Act. ${ }^{19}$

\section{The Lancaster Sanitary Reform}

Lancaster thus played a vital role in sparking Owen's interest in Anatomy and he left the city in 1824 to continue his medical education at the University of Edinburgh. His time in Edinburgh was however short lived and he followed the advice of John Barclay (1758-1826), the eminent Scottish anatomist, to continue his studies at St. Bartholomew's Hospital, London in 1825. It was here where he came under the influence of John Abernethy (1764-1831) and served as a prosector upon his arrival in London. ${ }^{2}$ Owen became a member of the Royal College of Surgeons in August of the following year. In 1827, Owen, at the age of 22, 
became assistant Conservator of the Hunterian Museum of the Royal College of Surgeons to William Home Clift (1775-1849). Owen excelled as a dissector and this was most likely due to his apprenticeship(s) in Lancaster. His abilities had not gone unnoticed and Abernethy, then President of the College of Surgeons, urged his pupil to undertake the mammoth task of cataloguing the recently purchased collection of John Hunter (1728- 1793). ${ }^{2,9}$ Owen's career progressed further and the following year saw him being appointed as lecturer in Comparative Anatomy at St. Bartholomew's Hospital. One of his first publications, Memoir on the Pearly Nautilus (1832), followed and received critical acclaim. ${ }^{2}$ In 1834 Owen was elected as Hunterian Professor of Physiology and Anatomy. In July 1835 Owen married Caroline Amelia Clift in St. Pancras Church, the only daughter of William Clift, by whom Owen had one son who received his grandfather's name, William Owen (born on 6 October 1837). ${ }^{2,3}$

Cholera reached England in the summer of 1831 but was only formally recognized in October 1832. ${ }^{20,21}$ The epidemic reached the cities of London and Manchester and Lancaster was not spared. Lancaster experienced population growth in the early 1800's; increasing from 9,000 in 1801 to 10,144 in 1821 and witnessed a growth spurt by 1841 to reach a total of 14,075 residents. ${ }^{3}$ This growth overlapped with Lancaster's cholera epidemic of 1832 and a decline in the shipping trade. The growth in population is likely the result of industrial expansion and the then existing railway to the town. ${ }^{3,20,23}$ Lancaster's golden age as a port gradually came to an end at the turn of the eighteenth-century. West Indian trade slowly declined and the most dramatic year was in 1803. The lucrative traffic bringing casks of coffee and cocoa, sugar, palm oil, bales of cotton and timber to one of England's major ports, declined from 42 ships the previous year to 17 by $1804 .^{23}$ Nevertheless, the industrialisation of Great Britain and, according to Cox (2012), and the further increase in immigration of the Irish after the potato famine in later years fuelled Lancaster's population growth during the 
nineteenth century. ${ }^{22,24}$ Cholera's arrival in Lancaster via the trade routes coincided with the rapid increase in population, inadequacies in medical care, poor standards of sanitation and poor water supply. ${ }^{20,25}$ The Lancaster Street Improvement Act of 1824 and the efforts of David Campbell (1749-1832), a local physician best known for his work on the 1784 typhus outbreak, was aimed at installing sewers and keeping the town's streets clean. ${ }^{26}$ The efforts of Campbell were noble but Lancaster was later faced with dire public health issues due to the growing numbers and poor sanitation. England's initial push for sanitary reform came in the 1840s with the establishment of the local boards of health under the Public Health Act 1848 and most of the dramatic changes to Lancaster's public health efforts would not take effect before the turn of the nineteenth-century through the Lancaster Board of Health. ${ }^{25,27}$ Peterson reports that the city-dwellers in England characteristically practiced private-lot waste removal. This entailed the discharge of refuse and the content of privy pots upon adjoining land and also into the streets. ${ }^{27}$ The same dismal sanitary conditions were found in Lancaster and Owen, in his report of 1845 to the Commission of Inquiry into the Health of Towns, noted that the courts and yards were riddled with human excrement. ${ }^{25}$ Owen was approached on 17 April 1843 by Sir James Robert George Graham, (1792-1861), then Home Secretary, to serve on the committee to investigate best practices for the management of sewerage. Owen's involvement in Sanitary Reform was delegated to report on the state of his native town. He continued to serve on this commission until 1846 despite his busy schedule of lectures, research and being appointed as Conservator of the Royal College of Surgeons in $1842 .^{2}$ The Commission was chaired by Lord Robert Grosvenor (1801-1893), a British courtier and politician, and the members of the commission included the social reformer, Sir Edwin Chadwick K.C.B. (1800-1890), the physician Thomas Southwood Smith (1788-1861), Owen, and Richard Lambert Jones (1783-1863), a London business man. Hamlin in 1992 writes that 
Owen and Smith were orthodox Chadwickians in their view and Grosvenor was sympathetic and pliable. The only neutral party within the commission was Jones. ${ }^{28}$

Owen frequently travelled between London and Lancaster in 1844 during the months of September and October. ${ }^{2}$ His excursions to the poorer areas of Lancaster, typically the worst affected, were done in the company of the resident medical officer and the well-known architect, architectural historian and sanitarian, Edmund Sharpe (1809-1877). ${ }^{25}$ The most deplorable conditions were found in the poorer areas in which the houses were typically not connected to drains and relied on cesspools and midden heaps. In his report Owen described Dyehouse Lane where the ash and privy pots were emptied into the cellar of the dwellings. The intention was for the local farmer to collect the night soil for its use as fertiliser. However, the cellars proved to be inaccessible and this resulted in large accumulations of human waste. The smell inside these dwellings was unbearable and the tenants, typically isolating themselves from the stench emanating from the court and streets, had no choice but to leave their doors and windows open and choose the lesser of two evils. Matters were made worse when it rained and one Medical Officer was 'compelled to quit his patient as soon as possible'. ${ }^{25}$ Conditions in Boar's Head Yard, that was later demolished, were similar and the content from the middens and pigsties accumulated in the yard. This in turn was emptied out into the road on a regular basis. The appalling conditions were the major considering factor for the high suicide rate in the town as well as alcohol abuse. ${ }^{23}$ The statistical data in Owen's report documents that $16.77 \%$ of all fatalities between 1838 and 1844 were due to epidemics. Infant mortality rates were high and Owen refers to this when he writes that 'the wife of John Hudderall had managed better than her neighbours, and had reared two out of five children'. ${ }^{25}$ The main issues in Lancaster were the lack of household sewage systems and the supply of water. $^{25,29}$ The discarded waste contaminated the wells that were the universal source for domestic water use, as well as the groundwater. ${ }^{25}$ Owen relied on Sharpe's drawings and 
maps of the existing sewage system as well as estimated costs to construct a new system within the town. ${ }^{29}$ The system proposed by Sharpe and then installed within the city provided household and surface drainage. ${ }^{23,29}$ Many improvements followed during the 1850 s and Sharpe, in his capacity as mayor, was at the forefront of the reform of the town. ${ }^{29}$ One of the most dramatic changes included a new cemetery at the moor. The architectural practice of Sharpe, founded in 1835 in Lancaster, drew up the plans of the chapels and these are currently grade II listed buildings. ${ }^{30}$ Owen recommended that the intramural burial sites within the town were highly unsuitable and there was reason to believe that the soakage reached the wells. ${ }^{23,25}$ This appears to be in line with Chadwick's miasma or filth theory of disease and was a common impression among many until the acceptance of the germ theory of disease. ${ }^{31}$ The miasma theory held that communicable diseases such as cholera were caused by pollution or "bad air" emanating from rotting organic matter. Owen later (1889) wrote a letter from his retirement home at Sheen Lodge (Richmond Park, London) to the editor of the Lancaster Observer in which he comments on the new water supply of the town (Fig. 2B). The discussion between the two townsfolk documented by Owen (Fig. 2B) was as follow:

'Eh! Betty! thou'st [thou hast; you have] put a power o'tea [a lot of tea] i't [in the] pot to neet [tonight].'

'Nay! Jennie!' (responded the hostess) 'it's nobbut [nothing but; only] t'new Watter [the new water].'

The changes to the town were gradual and Sharpe's report of 1876 provides a detailed account of the many challenges faced as well as the bureaucracy amongst the senior officials of the town. ${ }^{29}$ To date, some of the original cast iron grids from the reform can still be seen in 
the roadways of Lancaster and either have a date or LBH (Lancaster Board of Health) as an inscription.
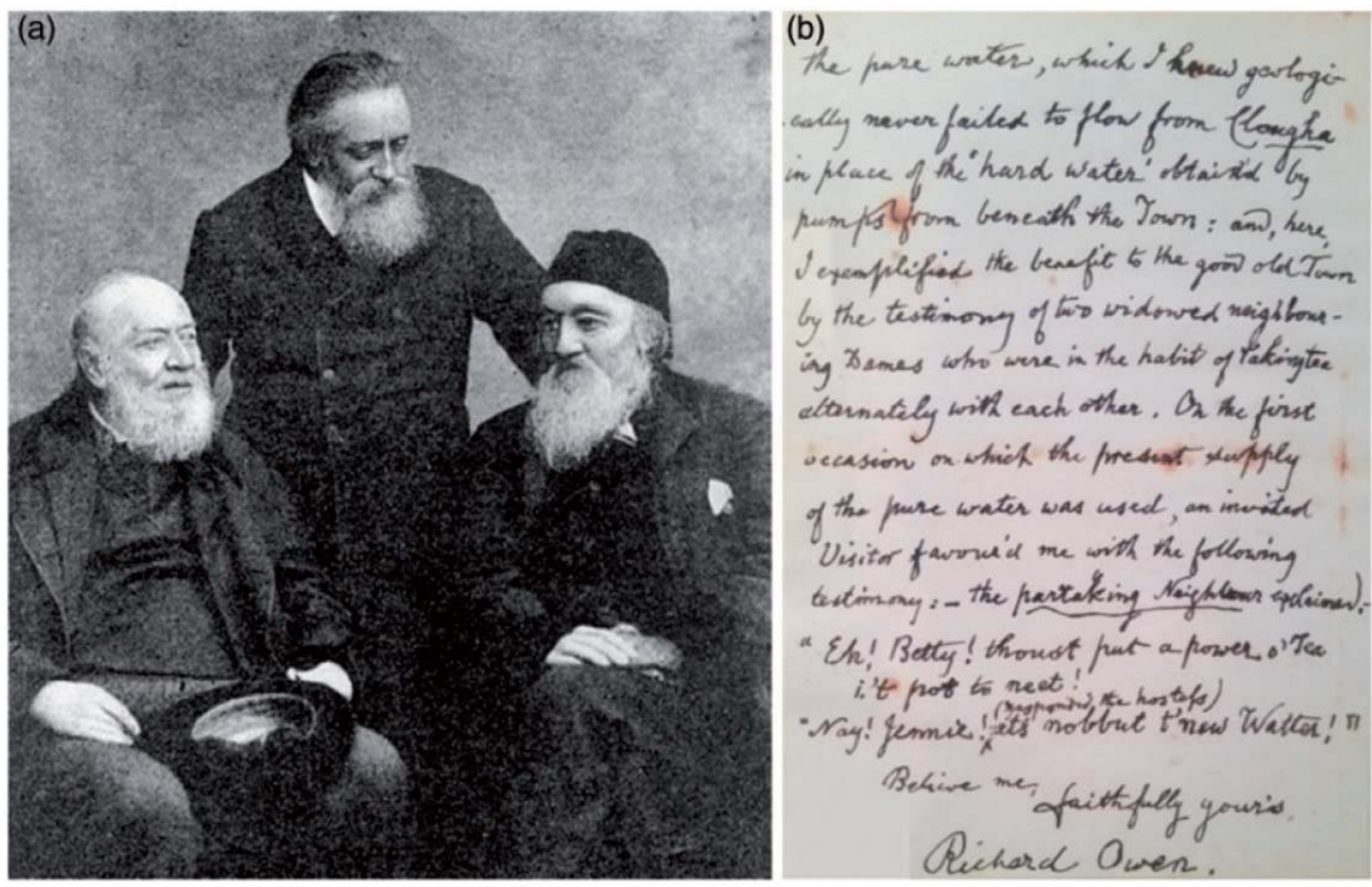

Fig. 2. A: Sir Richard Owen (1804-1892) (right) amongst the great sanitarians, Sir Edwin Chadwick (1800-1890) (left) and Sir Benjamin Ward Richardson (1828-1896) (middle), of Victorian England with. B: A letter written by Owen in 1889 at Sheen Lodge to the editor of the local newspaper, Lancaster Observer, in which he recalls a discussion between two neighbouring townsfolk on the new water supply (image courtesy of Lancaster City Museum).

\section{Owen's remembrance in Lancaster}

Owen's service to the Sanitary Commission drew to a close and his career flourished in the succeeding years. November 1844 was marked by the arrival of various paleontological 
specimens from across the globe at the Owen residence and he continued his work on the report on Lancaster in November 1844. It was during this time that he was offered the presidency of the Geological Society but declined due to his excessively busy schedule. ${ }^{2} \mathrm{He}$ later, from 1856 to 1884, became the Superintendent of the Natural History Department of the British Museum where he devoted much of his time and his efforts. These efforts eventually resulted in the transfer of the natural history collections from the British Museum to newly established premises at South Kensington, now known as the Natural History Museum. ${ }^{5,9}$ The final years of Owen's career were at the Natural History Museum until his retirement in December 1883. This was also the year he was knighted as Knight Commander of the Order of the Bath and he continued to live at Sheen Lodge, a residence presented to him as a gift from Queen Victoria, until his death in 1892. ${ }^{2,9}$ Sir Richard Owen sadly outlived both his only son and wife and his death came a few days after the first Old Lancastrians' Dinner that was held on 6 December 1892. The dinner was scheduled more than a year after the establishment of the Old Lancastrians Club on 27 April 1891 and Owen's health did not permit him to attend the event. ${ }^{3}$ Owen was survived by his three grandchildren and daughterin-law Emily. ${ }^{2}$ His love for his hometown remained throughout his life and, in his 86th year in 1890, he had these words to say of his beloved Lancaster: ${ }^{12}$

'I have never allowed my grateful memory of my birthplace and the education I received there to cool. Since I retired from my museum work the recollections of the benefits I received at Lancaster have brightened my leisure hours and friendly memories have returned.'

Sir Richard Owen continues to form part of Lancaster’s legacy. He was considered a hero by many and has even been honoured in a poem written by William Sanderson (18041848), an author to the Lancaster Gazette during the period and presented in 1842 at a dinner hosted in the Lancaster Assembly: ${ }^{3}$ 
'And Owen! though you differ in pursuit,

Worthy you are to be your friend's compeer;

In Cuvier's steps with genius as acute,

Onward you press; success in your career;

Beasts, birds, and insects, reptiles, fishes mute.

Your speculation — then, with judgment clear,

As you compare their frame with that of man

You trace throughout one systematic plan.'

Owen, along with Whewell, was known as one of the Great Twin Brethren of Lancaster and he always received a fantastic welcome in his hometown whenever he visited. $^{3,12,23}$

Sir Richard Owen has also been placed among the intellectuals of the Victorian era and features on the pedestal of the Victorian statue in Dalton Square, Lancaster. This statue was a gift to the city by Lord Ashton (1842-1930), formerly Mr. James Williamson and a prominent businessman, and was completed in $1907 .{ }^{16}$ Owen is depicted alongside Sir William Turner, Edward Frankland, Charles Darwin and Joseph Lister. ${ }^{32}$ Lancaster celebrates $^{2}$ one of its sons and his admiration continues officially through the Sir Richard Owen Surgical Society of the medical students at Lancaster Medical School and leisurely at the Sir Richard Owen Pub, 4 Spring Garden Street, Lancaster. 


\section{Conclusions}

The lifetime achievements of Sir Richard Owen without a doubt surpassed all expectations. His legacy reverberates across the globe as a result of his hard work and scientific vigour. His apprenticeship to the local apothecary-surgeons and the time spent at Lancaster Castle provided ample opportunity for him to become a skilled dissector and anatomist. These formative years would later prove to be a great benefit to his academic career. Owen made a significant contribution to Lancaster’s Sanitary Reform. These efforts are typically overlooked due to his achievements in anatomy, geology and palaeontology. His love for his hometown remained throughout his life and he always received a sincere welcome whenever he visited. His appointment as a member of the Health of Towns resulted in a major reformation in both Lancaster's water supply and sewage system. Owen also suggested the establishment of a new cemetery on the outskirt of the town. This was done in order to prevent any outflow into the groundwater and this suggests that he, at that time, was a proponent, like Chadwick, of the miasma theory of disease.

\section{Declaration of conflicting interests}

None declared.

\section{Acknowledgements}

The authors would like to thank Lancaster Royal Grammar School for the provision of copies of the image of the entries of Sir Richard Owen and Sir William Whewell into the school register as well as the Lancaster City Museum. Furthermore, the authors would like to thank 
Professor Richard Dutton (Humanities Distinguished Professor), Department of English, Ohio State University, for his assistance with the interpretation of Owen’s letter.

\section{References}

1. Mullen T. Sir Richard Owen: The man who invented the dinosaur, http://www.bbc.co.uk/news/uk-england-lancashire-31623397 (2015, accessed 7 June 2015).

2. Owen RS. The life of Richard Owen. Volume 1. New York: D. Appleton, 1894.

3. Fleury C. Time-honoured Lancaster: Historic notes on the ancient borough of Lancaster. Lancaster: Eaton \& Bulfilld, 1891, pp. 266-274.

4. Owen R. Darwin on the Origin of Species. Edinb R 1860; 3: 487-532.

5. Bett WR. Sir Richard Owen; 1804-92. Ann R Coll Surg Engl 1954; 15(4): 272-3.

6. Hedley BJ. Richard Owen, William Whewell, and the Vestiges. Brit J Hist Sci 1977; 10: 132-145.

7. Giovanni C. Richard Owen, Morphology and Evolution. J Hist Biol 2001; 34(3): 481-515. 
8. Modarai B, Sawyer A, Ellis H. The glands of Owen. J R Soc Med 2004; 97: 494-495.

9. Rupke N. Richard Owen: Biology Without Darwin. Chicago: University of Chicago Press, 2009.

10. Dobson J. Anatomical eponyms: being a biographical dictionary of those anatomists whose names have become incorporated into anatomical nomenclature, with definitions of the structures to which their names have been attached and references to the works in which they are described. London: Bailliere, Tindall \& Cox, 1946, p. 162.

11. Murray AL. The Royal Grammar School Lancaster. A History. Cambridge: W. Heffer \& Sons LTD, 1951.

12. Roper WO. Materials for the history of Lancaster. Remains: historical and literary. Connected with the palatine counties of Lancaster and Chester. Manchester: Chetham Society, 1907, pp. 309-311.

13. Cameron JS, Hicks J. High blood pressure and the kidney: The forgotten contribution of William Senhouse Kirkes. Kidney Int 2000; 57; 724-734.

14. Lancaster Gazette, 6 September 1817. 
15. Lancaster Gazette, 24 March 1827.

16. Turner AL. Sir William Turner K.C.B, F.R.S. Professor of Anatomy and Principal and Vice-Chancellor of the University of Edinburgh: A Chapter in Medical History. Edinburgh and London: William Blackwood and Sons, 1919.

17. Sailor D. The county "Hanging Town": Tails, executions and imprisonment at Lancaster Castle. Lancaster: Challenge Publishing, 1994.

18. Bailey JB. The diary of a resurrectionist, 1811-1812, to which are added an account of the resurrection men in London and a short history of the passing of the Anatomy Act. London: Swan Sonnenschein \& Co, Limited, 1896.

19. Richardson R.. Death, Dissection and the Destitute: The Politics of the Corpse in PreVictorian Britain. London: Phoenix Press, 2001.

20. Howson G. The Cholera Outbreak of 1832 in Lancaster. Contrebis 2003; 28: 42-45.

21. Litsios S. Charles Dickens and the movement for sanitary reform. Perspect Biol Med 2003; 46(2): 183-199. 
22. Walton JK. The treatment of pauper lunatics in Victorian England: the case of Lancaster Asylum, 1816-1870. in Scull A. Madhouses, Mad Doctors and Madmen. London: Athlone Press, 1981, p. 170.

23. Janes DC. Old towns and Cities: Lancaster. North Yorkshire: The Dalesman Publishing Company Ltd, 1974.

24. Cox C, Marland H, York S. Emaciated, Exhausted, and Excited: The Bodies and Minds of the Irish in Late Nineteenth-Century Lancashire Asylums. J Soc Hist 2012; 46(2): 500-24.

25. Owen R. Health of towns commission report on the State of Lancaster. London: W Clowes and Sons, 1845

26. Howson G. The Lancaster doctors: Three case studies. In: Aspects of Lancaster edited by Sue Wilson. Barnsley: Wharncliffe Books, 2002, pp. 53-62.

27. Peterson JA. The Impact of Sanitary Reform upon American Urban Planning, 1840-1890. J Soc Hist 1979; 13(1): 83-103.

28. Hamlin C. Edwin Chadwick and the Engineers, 1842-1854: Systems and Antisystems in the Pipe-and-Brick Sewers War. Technol Cult 1992; 33(4): 680-709. 
29. Sharpe E. A History of the Progress of Sanitary Reform in the Town of Lancaster from 1845 to 1875; And An Account of Its Water Supply. Lancaster: E \& JL Milner, 1876.

30. Hartwell, C, Pevsner N. The Buildings of England: Lancashire North. London: Yale University Press, 2009.

31. Abbott SW. What Constitutes a Filth Disease? Public Health Pap Rep 1890; 16: 30-42.

32. Wessels Q, Correia JC, Taylor AM. Sir William Turner (1832-1916) - Lancastrian, anatomist and champion of the Victorian era. J Med Biogr 2015, Mar 3. 